\title{
FELINE ARTICULAR CARTILAGE IN THE PRENATAL AND EARLY POSTNATAL PERIODS. A SCANNING ELECTRON MICROSCOPIC STUDY
}

\author{
D. HORKÝ
}

\begin{abstract}
Department of Histology and Embryology, Faculty of Medicine Masaryk University, 66243 Brno, Czech Republic
\end{abstract}

Received March 9, 1993

\begin{abstract}
Horký D: Feline articular cartilage in the prenatal and early postnatal periods. A scanning electron microscopic study. Acta vet. Brno, 63, 1994: 33-39.

The structure of articular cartilage from the femoral head was studied in the domestic cat by scanning electron microscopy. Tissue samples were collected from foetuses at 30,40 and 48 days after fertilization and from young animals at 4,8 and 43 days after birth.

At 30 and $\mathbf{4 0}$ days after fertilization, the cartilage surface showed numerous elevations accumulated closely to each other. A fracture plane running through the cartilage collected at 40 days revealed chondrocytes situated in three layers. At 48 days the surface chondrocytes began to aggregate into groups of 4 to 6 cells and, amongst the groups, smooth areas appeared. The entire surface was covered by a chondrosynovial membrane.

The appearance of articular cartilage remained without noticeable changes after birth. At 4 days there were still groups of elevations seen in the previous period but they consisted of only 2 to 4 cells. These were often arranged in pairs with a shallow groove on the surface. The smooth areas increased in size. At 8 days some of the chondrocytes were encircled with a vallum and furrow. At 43 days the surface differed in appearance in different regions. There were still regions similar in structure to those at 8 days but the majority of the surface was restructured. The number of surface chondrocytes with the vallum and furrow had been reduced while the smooth regions had extended. The surface cartilage had attained the appearance of a young adult cartilage.
\end{abstract}

\section{Articular cartilage, domestic cat, scanning electron microscopy, perinatal development}

Many new observations on the surface of articular cartilage have been made as a result of the advent of scanning electron microscopy. The first studies in experimental mammals showed that the cartilage surface was not as smooth as had generally been thought (Cameron and Robinson 1958; Silberger et al.; Davies et al. 1962; B a r n e t t et al. 1963). Four types of surface topography have been recognized: a) undulations with furrows and $1 \mu \mathrm{m}$ high ridges located at distances of several $\mu \mathrm{m}$; b) fine undulations with ridges about $0.2-1 \mu \mathrm{m}$ apart; ) elliptical depressions 10-30 $\mu \mathrm{m}$ in diameter; d) ovoid elevations $10-20 \mu \mathrm{m}$ in diameter. The latter category is very frequent in the cartilage of young animals; the number of elevations gradually decreases with age. The surface of human articular cartilage has been described by M c Gall (1968a, b) in necropsy materials and parallel ridges have been observed. A similar surface pattern has been found in adult articular cartilage by Walker et al. (1969), while Gardner and Woodward (1969), Gardner etal. (1975), Hesse and Hesse (1978), Long more and Gardner (1978) demonstrated large $(400 \mu \mathrm{m})$ depressions, with smaller $(20-40 \mu \mathrm{m})$ wells on their bottoms, on the surface of articular cartilage in guinea pigs. Similar findings have been made in man ( $\mathrm{Pu} \mathrm{s} \mathrm{ch} \mathrm{m} \mathrm{a} \mathrm{n} \mathrm{n}$ 1978). Other studies have been concerned with the structure of articular surfaces under physiological conditions (Cotta and Puhl 1970; Clarke 1971a, b, 1973, 1974; Fujita et al. 1971; Zimny and Redler 1972, 1974; Puhl and Iyer 1973; Puhl 1974; Wolf 1974a, b; Doige and Horowitz 1975; Draenert and Draenert 1978; Gardner et al. 1981; Horký 1986), after changes brought about by experimental conditions (Ghadially et al. 1974, 1976, 1978; Moschurchak and Ghadially 1978; Cylwik 1978; O'Conn or 1984) or during pathological processes (In oue et al. 1969; B ozděch et al. 1972, 1974, 1977; Horký et al. 1974a, b, 1975; Redler 1974; Korkala et al. 1984; Elliott 1986). Some studies have described the structure of articular cartilage during ontogeny (for review see Horký 1986, 1987a, b). Soon after they appeared, the studies were subjected to critical comments pointing to the possibility of artifacts formation due to the preparation procedures (Ghadially et al. 1974, 1976, 1977, 1978). Some authors have suggested that the water removed by dehydration should be replaced by another medium similarly to the procedures used in light or transmission electron microscopy (B lo e b a u m and Wils on 1980) or frozen materials should be used (Gard ner et al. 1981; Wil s on and Gardner 1984) to avoid artifacts resulting from fixation or dehydration. However, no matter what preparation technique was used, the surface of articular cartilage always remained uneven to a varying degree. The studies published so far have not given support to the observations of B lo e b a u m and Wil s on (1980) who achieved smooth surfaces of articular cartilage after the tissue had been immersed in a medium based on water soluble resin. In our opinion, a carefully performed method of scanning electron microscopy is still a useful tool in investigations of joint surfaces or other bone structures (De B on t 1986; Clark 1991). 


\section{Materials and Methods}

Samples of articular cartilage were collected from the femoral heads of 18 domestic cats of both sexes. The age categories sampled were: 30,40 and 48 days after fertilization and 4,8 and 43 days after birth. Three animals were used in each group.

Prior fixation, the samples were either treated with hyaluronidase solution $(0.1 \mathrm{mg} / \mathrm{ml})$ for $15 \mathrm{~min}$ at $20^{\circ} \mathrm{C}$ or washed in three changes of physiological saline for $15 \mathrm{~min}$ each. Either procedure was sufficient to remove the remains of synovial fluid from cartilage surfaces without producing changes in them. Samples of cartilage from animals in postnatal periods were always collected with the subchondral bone. Fixation was carried out in $10 \%$ formaldehyde of $4 \%$ glutaraldehyde for 10 days at least. The fixed specimens were dehydrated in increasing concentrations of ethanol and then dried at the critical point (Balzers SCD 040 apparatus). They were shadowed with gold and examined and photographed in a Tesla BS 300 scanning electron microscope.

\section{Results}

At 30 days after fertilization, the cartilage which covered the surface of the femoral joint was very uneven (Plate I, Fig. 1). Numerous elevations, clustered together, protruded above the surface with no smooth areas between them.

At 40 days the cartilage surface had an appearance similar to that seen at the previous stage. On a fracture plane it can be seen (Plate I, Fig. 2) that the surface uneveness was due to superficially located chondrocytes. In the topmost layer, the chondorocytes were distributed parallel to the surface. Below this, there were 4 to 5 layers of densely accumulated cell, composing the surface layer rich in chondrocytes (Fig. 2). The middle layer consisted of chondrocytes arranged in tiers perpendicular to the surface (Plate II, Fig. 3). Chondrocytes of this layer were fewer in number, as compared with the upper layer, but were larger in size and located in lacunae (Fig. 3).

The intercellular matter, in a greater amount than in the surface layer (Fig. 2), had a well developed fibrillar component (Fig. 3). Collagen fibrils arranged in bundles formed networks in the ground amorphous substance or produced „baskets“ for chondrocytes situated in lacunae (Fig. 3). The deep layer contained chondrocytes similar in size to those of the surface layer. The cells were scattered in an excess of intercellular matrix. The chondrocyte distribution and the proportion of cellular to intercellular components of this layer remained without noticeable changes in later periods.

From day 48 on, the surface of articular cartilage underwent considerable changes. Although the elevations retained their dome- or spindle-like shapes, their distribution changed markedly (Plate II, Fig. 4). While at 30 and 40 days the surface was formed by densely but regularly accumulated elevations, at 48 days these structures aggregated into groups of 2 to 4 cells alternating with areas of smooth (Fig. 4) or finely filamentous surface. The latter areas were most likely the precipitated remnants of synovial fluid; some cell detritus was also observed.

After birth the changes in the cartilage surface were even more pronounced. At 4 days the surface was much less uneven than at the previous stage (Plate III, Fig. 5). The number of chondrocytes continued to decrease and the cells were located in distinctly separated groups of 2 or 4 . The groups of four consisted of two cell pairs close to each other (Fig. 5). In some cases, the surface of elevations showed shallow grooves which gave an impression of dividing cells in the lacuna (Fig. 5). Due to a reduction in the number of elevations, the areas amongst the cells increased in size and their surface was arranged into fine folds (Fig. 5). Similarly to the previous period, the remnants of synovial fluid presented as filamentous structures.

In the following periods, the process of „sinking“ and separation of the elevations from the surroundings continued (Plate III, Fig. 6). At 8 days after birth, the elevations were arranged into columns or small groups. Some were encircled with a vallum separating the cell 
from the intercellular matrix. This was finely wrinkled and often extended also over the elevations.

At 43 days after birth, the appearance of the articular surface varied between the regions. The areas not subjected to pressure forces showed surfaces similar in appearance to those of perinatal periods (Plate IV, Fig. 7). They consisted of groups of more or less elevated chondrocytes without valla or grooves. Amongst the groups there were areas covered by a finely wrinkled chondrosynovial membrane (Fig. 7). The regions under pressure (Plate IV, Fig. 8) showed chondrocytes in the process of ,sinking“. The number of these cells underwent further reduction and they occurred on the cartilage surface singly or in pairs (Fig. 8). In both instances there was an encircling furrow and a vallum (Fig. 8). The whole region (pair) was distinctly sunken below the level of the surrounding intercellular matrix, which often created extensive depressions, referred to as trapped pools. The surface of the intercellular matrix was folded into wide ridges. On the bottoms of the depressions, an indication of intercellular septa could be seen (Fig. 8).

\section{Discussion}

The first information on the surface of articular cartilage in the rabbit and dog was provided by E1li ot t as early as in 1936. Using light microscopy, he described chondrocytes located at the cartilage surface and found empty envelopes as signs of their degeneration. Later the structure and appearance of articular cartilage have been studied in many experimental animals (see the introduction) but, surprisingly, not in domestic cats either adult or foetal.

The development of feline articular cartilage in the periods reported in this study was in agreement with the literature data and our previous results (B o z e $\mathrm{ch}$ et al. 1990; Hor ký 1983, 1986, 1987, 1989, 1991a, b, 1993). These concern human articular cartilage as well as that of experimental mammals in both prenatal and postnatal stages of development.

The surface of articular cartilage at early stages of feline development showed numerous elevations, which was similar to the findings published by Moschurchak and Ghadi ally (1978), Long more and Gardner (1978) and to our earlier observations in bovine and human cartilage (Horky 1983, 1986, 1987). These elevations are based on the surface layer chondrocytes. This fact, much discussed earlier, has been unambiguously confirmed by comparison of interference, transmission and scanning electron microscopic studies. It is obvious (Hork ý 1984) that, particularly in embryonic tissues, fixation and dehydration artifacts are common features due to high water content of the ground amorphous substance and low amounts of proteoglycans and fibrillar components (F r e e $\mathrm{m}$ a $\mathrm{n}$ and Meachim 1973). With increasing age the number of chondrocytes is reduced in every cartilage layer (S to $\mathrm{k}$ well 1967). The amount and arrangement of the fibrillar component of intercellular matrix is also subjected to changes, as shown erlier by transmission electron microscopy in cattle and pigs (Horký 1983, 1991c, d) and in man (Horký 1980, $1991 \mathrm{a}, \mathrm{b})$. The same changes were demonstrated in this work. Scanning electron microscopy, as a convenient tool for the study of fibrillar components, has been used not only in previous research ( $\mathrm{McCa}$ Cll 1968a, b) but also in recent investigations (De B on t et al. 1986; Elli ot 1986; Clark 1991) and has provided results comparable with those obtained by transmission electron microscopy (Ghadially 1983; Horký 1991a, b).

The process of "sinking" showed by chondrocytes or their groups in the cartilage before and, particularly, after birth has been reported by almost all the authors studying this tissue. The gradual disappearance of chondrocytes and the appearance of trapped pools are apparently essential for maintainig the joint function because the trapped pools are present in regions under pressure ( W a l ker et al. 1969). As suggested by a number of authors ( $\mathrm{Ch}$ a p- 
puis et al. 1983; Gangel 1984; Swann etal. 1985; Sabiston and Adams 1989), this arrangement plays a major role in articular lubrication. However, our observations failed to show large pools, up to $400 \mu \mathrm{m}$ in diameter, reported by Gardner and Woodw ard (1969) in the articular cartilage of the guinea pig. Clarke (1971a) has put forward a view that the pools are created by the collapse of chondrocytes in lacunae located under the boundary layer, while the elevations are due to the presence of thick intercellular matrix. In this study, Cl arke removed the surface layer of the articular cartilage by tangential section and demonstrated by scanning electron microscopy that the diameter of lacunae corresponded to the size of surface depressions. Our findings confirm this view. In our experiments the damage to chondrocytes caused by sectioning was avoided by using fracturing. This provided information of the surface structures as well as on the distribution of cells in the cartilage layers. Moreover, the complementary fracture faces showed lacunae with chondrocytes. This approach allowed us to gain an insight into the arrangement of cells and intercellular matrix in each layer from the surface to the subchondral bone.

\section{Vzhled kloubní chrupavky kočky v prenatálním a časném postnatálním období. SEM studie}

Byl studován vzhled kloubní chrupavky fetů kočky stáří 30,40 a 48 dní po oplození a devíti mláđat stáři 4,8 a 43 dny po narození. Chrupavka byla odebírána pro úcely rastrovací elektronové mikroskopie vždy z hlavice kyčelního kloubu, poprípadě byla odebrána hlavice celá a vzorky byly zpracovány obvyklým způsobem.

V období 30. a 40. dne po oplození jsou na povrchu chrupavky patrny četné vyvýšeniny hustě nahloučeny vedle sebe. Na lomu chrupavkou 40 . dne vývoje jsou již chondrocyty zřetelně uspořádány do tř́i vrstev. Toto uspořádání si ponechávají po celou další dobu.

48. dne intrauterinního vývoje se začínají povrchově uložené chondrocyty shlukovat do skupin po 4-6 buňkách a mezi skupinami se začínají objevovat hladké plochy. Jak prominence, které jsou způsobeny buňkami, tak hladké plochy mezi skupinami chondrocytů jsou kryty chondrosynoviální membránou.

Vzhled kloubní chrupavky se dále podstatně mění v období po narození. 4. dne jsou ještě patrny obdobné shluky vyvýšenin jako u předchozího stadia. Jsou však složeny ze 2-4 buněk, príičemž vždy dva pahrbky leží těsně u sebe a v některých př́ipadech je na jejich povrchu patrný mělký příčný zářez. Víceméně hladký povrch mezi skupinami se zvětšuje. V 8. dnu po narození se poprvé setkáváme u některých chondrocytů s obkružujícím valem, který přechází do okolního povrchu zářezem.

Povrch kloubní chrupavky 43. dne po narození je regionálně odlišně stavěn. Můžeme pozorovat okrsky, které se značně podobají kloubní chrupavce např. v období 8. dne po narození, avšak převážná většina povrchu hlavice kyčelního kloubu je stavěna odlišně. Dochází již ke značné redukci počtu povrchově uložených chondrocytủ, které jsou obkrouženy různě hlubokou brázdou a v některých případech je patrný i val, který se spolu s buňkou zanoruje do mezibuněčné hmoty. V důsledku redukce počtu chondrocytů se značně zvětšují hladké plochy, takže chrupavka nabývá vzhledu mladé dospělé chrupavky.

\section{Внешний вид суставного хряща кошки в прөдродовой и послөродовой пөриоды}

Проводили исследование внешнего вида суставного хряща плодов кошки в возрасте 30,40 и 48 суток после оплодотворения и девяти детенышей в возрасте 4, 8 и 43 суток после рождения. Отбор хряща проводили для целей растровой микроскопии всегда с головки тазобедренного сустава или проводили отбор всей головки. Препараты обрабатывали обычным способом. 
В период 30 и 40 суток после оплодотворения на поверхности хряща наблюдаются многочисленные, плотно скопленные бугорки. На изломе хряща 40 суток хондроциты уже четко распределены в три слоя. Данное распределение остается в течение всего последующего периода.

На 48 сутки внутриутробного развития начинается скопление поверхностно расположенных хондроцитов в группы по 4-6 клеток и между группами начинают появлятсья гладкие поверхности. Выступы, вызванные клетками, а также гладкие поверхности между группами хондроцитов прикрыты хондросиновиальной мембраной.

Внешний вид суставного хряща в дальнейшем проходит существенными изменениями в период после рождения. На 4 сутки все еще наблюдаются аналогичные скопления выступов как у предыдущей стадии. Однако они состоят из 2-4 клеток, при этом всегда два бугорка плотно расположены рядом и в некоторых случаях на их поверхности наблюдается мелкая поперечная зарубина. Более или менее гладкая поверхность между группами увеличивается. На 8 сутки после рождения впервые у некоторых хондроцитов встрещается окружающий вал, переходящий в окружающую поверхность зарубкой.

Поверхность суставного хряща по своему строению на 43 сутки после рождения регионально отличается. Можно наблюдать учаски, которые в значительной степени похожи на суставной хрящ, например, на 8 сутки после рождения, однако преобладающая поверхность головки тазобедренного сустава по строению отличается. Наступает уже значительное ограничение численности поверхностно расположенных хондроцитов, окруженных бороздой разной глубины, и в некоторых случаях наблюдается также вал, окунающийся совместно с клеткой в межклеточную массу. В результате ограничения численности хондроцитов значительно увеличиваются гладкие поверхности, следовательно, хрящприобретает вид небольшого взрослого хряща.

\section{References}

BARNETT, C. H.-COCHRANE, W.-PALFREY, A. J.: Age changes in articular cartilage of rabbits. Ann. rheum. Dis., 22, 1963: 389-400.

BLOEBAUM, R. D.-WILSON, A. S.: The morphology of the surface of articular cartilage in adult rats. J, Anat., 131, 1980: 333-346.

BOZDËCH, Z.-HORN, V.-HORKÝ, D.: Der normale und arthrotische Gelenkknorpel im Bilde der Rasterelektronenmikroskopie. Beitr. Orthop., 19, 1972: 313-318.

BOZDËCH, Z.-HORN, V.-HORKY, D.: Patogeneze artrózy. Čas. lék. ces., 113, 1974: 969-971.

BOZDĚCH, Z.-HORKÝ, D.-HORN, V.: Ultramicroscopic picture of hemophilic joint. Acta Facult. Med. Univ. Brunensis, 58, 1977: 85-88.

BOZDĚCH, Z.-HORKYY, D.-JANEČEK, M.: Chrupavka a synoviální tkáń lidského kloubu. Acta fak. med. Univ. Masaryk. Brunensis 1990: 1-150.

CAMERON, D. A.-ROBINSON, R. A.: Electron microscopy of epiphyseal and articular cartilage matrix in the femur of the newborn infant. J. Bone Jt Surg., 40-A, 1958: 163-170.

CLARK, J. M.: Variation of collagen fiber alignment in a joint surface: a scanning electron microscope study of the tibial plateau in dog, rabbit and man. J. Orthop. Res., 9, 1991: 246-257.

CLARKE, I. C.: Surface characteristic of human articular cartilage- a scanning electron microscope study. J. Anat., 108, 1971a: 23-30.

CLARKE, I. C.: Human articular surface contours and related surface depression frequency studies. Ann. rheum. Dis., 30, 1971b: 15-23.

CLARKE, I. C.: Correlation of SEM, replication and light microscopy studies of the bearing surfaces in human joints. In: Scanning Electron Microscopy 1973: 659-666. Eds.: O. Johari and I. Corvin, IIT Research Institute, Chicago, Illinois.

CLARKE, I. C.: Articular cartilage: a rewiev and scanning electron microscope study. II. The territorial fibrillar architecture. J. Anat. (Lond.), 118, 1974: 261-280.

COTTA, H.-PUHL, W.: Oberflächenbetrachtungen des Gelenkknorpels. Arch. Orthop. Unfall-Chir., 68, 1970: $152-164$.

CYLWIK, B.: Scanning electron-microscopical studies of the articular surface of rats with adjuvant-induced arthritis. Rheumatologia, 16, 1978: 217-224.

DAVIES, D. V.-BARNETT, C. H.-COCHRANE, W.-PALFREY, A. J.: Electron microscopy of articular cartilage in the young adult rabbit. Ann. Rheum. Dis., 21, 1962: 11-22. 
DE BONT, L. G. M.-LIEM, R. S. B.-HAVINGA, P.: Collagenous network in human femoral condyles. A light microscopic and scanning electron microscopic study. Acta Anat., 126, 1986: 41-47.

DOIGE, C.-HOROWITZ, A.: A study of articular surfaces and synovial fossae of the pectoral limb of swine. Can. J. Comp. Med., 39, 1975, 7-16.

DRAENERT, V.-DRAENERT, K.: Freeze-drying of articular cartilage. Scan. El. Micr., 111, 1978: $759-766$.

ELLIOTT, H. C.: Studies on articular cartilage. Amer. J. Anat., 58, 1936: 127-143.

ELLIOTT, S.: Scanning electron microscopy of antigen induced arthritic joints. I. Inflammatory cell interactions at synovial-meniscal surfaces during the Arthus responses. J. Rheumatol., 17, 1986: 401-407.

FREEMAN, M. A. R.-MEACHIM, G.: Ageing, degeneration and remodelling of articular cartilage. In: Adult articular cartilage. Ed.: Freeman, M. A. R. Alden Press, Oxford, Great Britain, 1973: 287-329.

FUJITA, T.-TOKUNAGA, J.-INOUE, H.: Atlas of scanning electron microscopy in medicine. Elsevier Publishing Company, Amsterdam, London, New York, 1971.

GANGEL, H.: Synovial fluid. In.: Diseases of the horses. Eds.: Dietz, O., Wiesner, E. S. Karger Ag., Basel, 1984.

GARDNER, D. L.-WOODWARD, D.: Scanning electron microscopy and replica studies of articular surfaces of guinea-pig synovial joints. Ann. Rheum Dis., 28, 1969: 379-391.

GARDNER, D. L.-McGILLIVRAY, D. C.: Surface structure of articular cartilage. Ann. Rheum. Dis., 30, 1971: 10-12.

GARDNER, D. L.-ELLIOTT, R. S.-GILMORE, R. S.-LONGMORE, R. B.: Microscopical appearance and organization of articular cartilage surfaces. Ann. Rheum. Dis., 34, 1975: 2-4.

GARDNER, D. L.-O'CONNOR, P.-DATES, K.: Low temperature scanning electron microscopy of dog and guinea-pig hyaline articular cartilage. J. Anat., 132, 1981: 267-282.

GHADIALLY, F. N.-AILSBY, R. L.-ORYSCHAK, A. F.: Scanning electron microscopy of superficial defects in articular cartilage. Ann. Rheum. Dis., 33, 1974: 327-332.

GHADIALLY, F. N.-GHADIALLY, J. A.-ORYSCHAK, A. F.-YONG, N. K.: Experimental production of ridges on rabbit articular cartilage: a scanning electron microscopic study. J. Anat., 121, 1976: 119-132.

GHADIALLY, F. N.-GHADIALLY, J. A.-ORYSCHAK, A. F.-YONG, N. K.: The surface of dog articular cartilage: a scanning electron microscopic study. J. Anat., 123, 1977: 527-536.

GHADIALLY, MOSHURCHAK, E. M.-GHADIALLY, J. A.: A maturation change in the surface of cat articular cartilage detected by the scanning electron microscope. J. Anat., 125, 1978: 349-360.

HESSE, I.-HESSE, W.: Die Ultrastruktur der normalen Gelenkknorpeloberfläche. Anat. Anz., 144, 1978 : 149-151.

HORKÝ, D.: Submicroscopic structure of the human joint cartilage. Acta vet. Brno, 49, 1980: 145-176.

HORKÝ, D.: Ontogenic development of the ultrastructure of bovine joint cartilage. Acta vet. Brno, 52, 1983: 103-130.

HORKÝ, D.: Ultrastruktura kloubní chrupavky a synoviální membrány skotu v ontogenezi. Acta Facult. Med. Univ. Brunensis, 57, 1984: 319.

HORKÝ, D.: Povrch lidské kloubní chrupavky v rastrovacím elektronovém mikroskopu. Acta Facult. Med. Univ. Brunensis, 59, 1986a: 60.

HORKÝ, D.: Ultrastructure of bovine articular cartilage between weeks 8 and 23 of prenatal development. Acta vet. Brno, 55, 1986b: 227-246.

HORKÝ, D.: Submicroscopic structure of bovine articular cartilage in prenatal and early postanatal period. Acta vet. Brno, 56, 1987: 3-18.

HORKÝ, D.: Submicroscopic structure of articular cartilage in human embrya six to eleven weeks old. Acta vet. Brno, 60, 1991a: 15-30.

HORKÝ, D.: Submicroscopic structure of human articular cartilage in the period between 19 to 38 weeks after fertilization. Acta vet. Brno, 60, 1991b: 111-126.

HORKÝ, D.: The submicroscopic structure of articular cartilage in swine in the early postnatal period. Acta vet. Brno, 60, 1991c: 323-334.

HORKÝ, D.: Submikroskopická stavba kloubní chrupavky dospělého prasete. Scripta medica, 64, $1991 \mathrm{~d}: 177$.

HORKÝ, D.: The ultrastructure of articular cartilage in the prenatal domestic cat. Acta vet. Brno, 63, $1993: 115-120$.

HORKÝ, D.-BOZDĚCH, Z.-HORN, V.: Ultrastruktura synoviální membrány a kloubní chrupavky při hemofilii $\mathrm{v}$ transmisním a rastrovacím elektronovém mikroskopu. Čas. lék. Ces. 113, 1974a: 777-781.

HORKÝ, D.-BOZDËCH, Z.-HORN, V.: Ultrastructure of the synovial membrane and articular cartilage in haemophilia in the transmission and scanning electron microscope. Folia Morphol. (Prague), 22, $1974 \mathrm{~b}: 330$-332.

CHAPPUIS, J.-SHERMAN, I. A.-NEUMANN, A. W.: Surface tension of animal cartilage as it relates to function in joints. Ann. Biomed. Eng., 11, 1983: 435-451.

INOUE, H.-KODAMA, T.-FUJITA, T.: Scanning electron microscopy of normal and rheumatoid articular cartilages. Arch. Histol. Jap. 30, 1969: 425-435.

KORKALA, O.-KARAHARJU, E.-GRONBLAD, M.-AALTO, K.: Articular cartilage after meniscectomy. Rabbit knees studied with the scanning electron microscope. Acta Orthop. Scand, 55, 1984, 273-278.

LONGMORE, R. B.-GARDNER, D. L.: Development with age of human articular cartilage surface structure. Ann. Rheum Dis. 34, 1975: 26-37.

LONGMORE, R. B.-GARDNER, D. L.: The surface structure of ageing human articular cartilage: a study by reflected light interference microscopy. J. Anat., 126, 1978: 353-365. 
McCALL, J. G.: Scanning electron microscopy of articular surfaces. Lancet, 2, 1968a: 1194.

McCALL, J. G.: Scanning electron microscopy study of human articular cartilage. M. Sc. Thesis, Univ. Strathclyde, 1968b.

McCALL, J. G.: Load deformation studies of articular cartilage. J. Anat., 105, 1969: 212-214.

MOSHURCHAK, E. M.-GHADIALLY, F. N.: A maturation change detected in the semilunar cartilages with the scanning electron microscope. J. Anat., 126, 1978: 605-618.

MOW, W. C.-LAI, W. M.-REDLER, I.: Some surface characteristic of articular cartilage. I. A scanning electron microscopy study and a theoretical model for the dynamic interaction of synovial fluid and articular cartilage. J. Biomech., 7, 1974: 449-456.

O'CONNOR, P.-BRERETON, J. D.-GARDNER, D. L.: Hyaline cartilage disected by papain-light and scanning electron microscopy and micromechanical studies. Ann. Rheum. Dis., 43, 1984: 320-327.

PUHL, W.: Micromorphology of the surface of normal articular cartilage. Z. Orthop., 112, 1974, 262-272.

PUHL, W.-IYER, V.: SEM observations on the structures of the articular cartilage surface in normal and pathological conditions. In: Scanning Electron Microscopy. Eds.: Johari, O. and Corvin, I. Research Institute, Chicago, Illinois, 1973: 675-682.

PUHL, W.-HAMACHER, P.: Die Abhängigkeit der Mikromorfologie der Gelenkknorpeloberfläche von belastungen. Anat. Anz., 144, 1978: 168-181.

PÜSCHMANN, H.: Scanning and transmission electron microscopic studies of the development of the joint surfaces. Anat. Anz., 143, 1978: 399-406.

QUINTERO, M.-MITROVIC, D. R.-STANKOVIC, A.: Cellular aspects of aging of the articular cartilage. II. Fissured condylar surface cartilage taken from "normal" and "arthrotic" knees. Rev. Rhum. Mal. Osteo-articul., 51, 1984: 445-449.

REDLER, I.: A scanning electron microscopic study of human normal and osteoarthritic articular cartilage. Clin. Orthop., 103, 1974, 262-268.

SABISTON, C. P.-ADAMS, M. E.: Production of catabolin by synovium from an experimental model of osteoarthritis. J. Orthop. Res., 7, 1989, 519-530.

SILBERGER, R.-SILBERGER, M.-VOGEL, A.-WETTSTEIN, W.: Ultrastructure of articular cartilage of mice of various ages. Am. J. Anat., 109, 1961: 251-275.

STOCKWELL, R. A.: The cell density of human articular and costal cartilage. J. Anat., 101, 1967: 753-763.

SWANN, D. A.-SILVER, F. H.-SLAYTER, H. S.: The molecular structure and lubricating activity of lubricin isolated from bovine and human synovial fluids. Biochem. J., 225, 185: 195-201.

WALKER, P. S.-SIKORSKI, J.-DOWSON, D.-LONGFIELD, M. D.-WRIGHT, V.-BUCKLEY, T.: Behavior of synovial fluid on surfaces of articular cartilage. A scanning electron microscope study. Ann. Rheum. Dis., 28, 1969: 1-14.

WILSON, V. H. F.-GARDNER, D. L.: The microscopic structure of fibrous articular surfaces. A rewiev. Anat. Rec., 209, 1984: 143-152.

WOLF, J.: Transition from synovial into chondral membrane. Folia Morphol. (Prague), 22, 1974a: 151-160.

WOLF, J.: Reinforcement of transitional zone between chondral and synovial membranes. Folia Morphol. (Prague), 22, 1974b: 161-164.

WOLF, J.: Blood supply and nutrition of articular cartilage. Folia Morphol. (Prague), 23, 1975: 197-209.

ZIMNY, M. L.-REDLER, I.: Scanning electron microscopy of chondrocytes. Acta Anat. (Basel),83, 1972: 398-402.

ZIMNY, M. L.-REDLER, I.: Morphological variations within a given area of articular surface of cartilage. Z. Zellforsch. Mikrosk. Anat., 147, 1974: 163-167. 


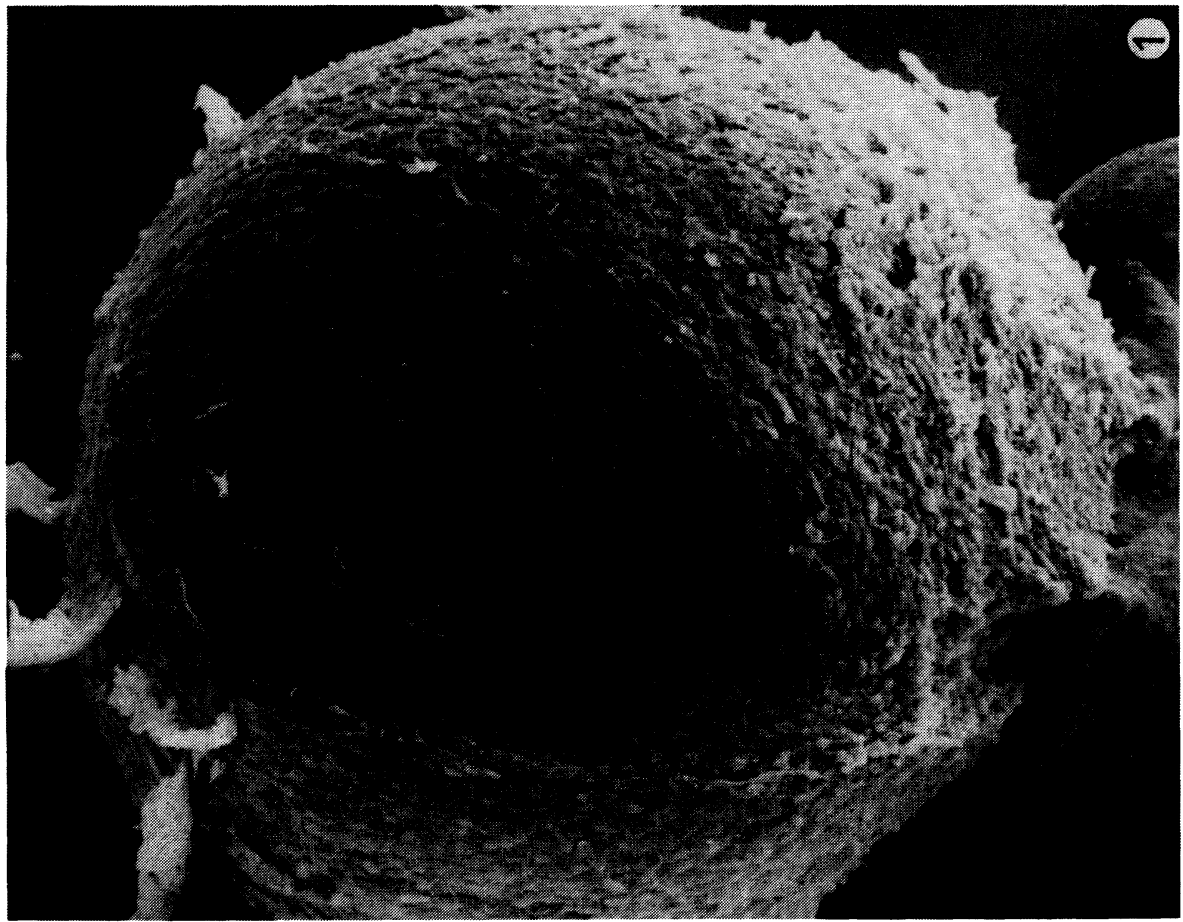

Fig. 1: Surface of articular cartilage from the femoral head of a feline foetus at 30 days. Numerous rounded elevations. $\times 200$.

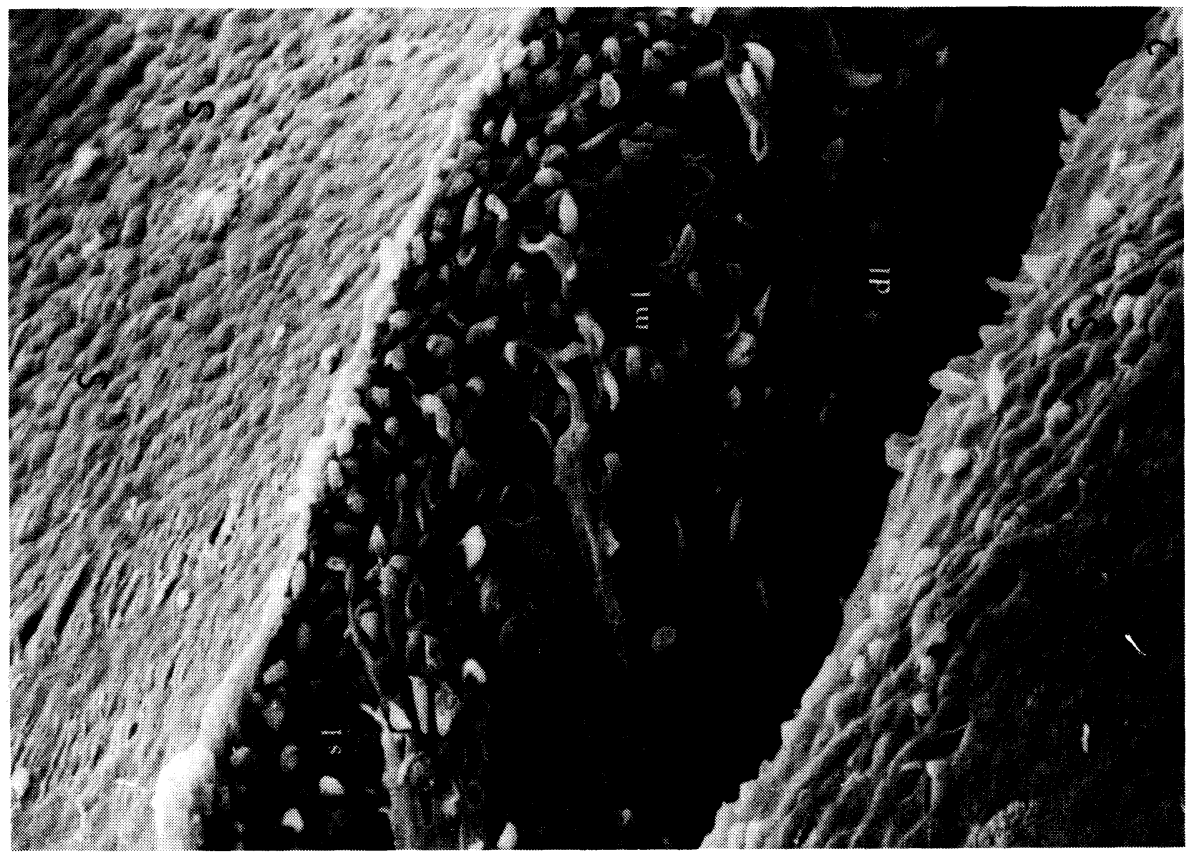

Fig. 2: Part of the surface of a fracture plane through articular cartilage at 40 days after fertilization. The surface with many elevations $(\mathrm{S})$. Surface $(\mathrm{sl})$, middle $(\mathrm{ml})$ and deep $(\mathrm{dl})$ layers. $\times 600$ 
Plate II.

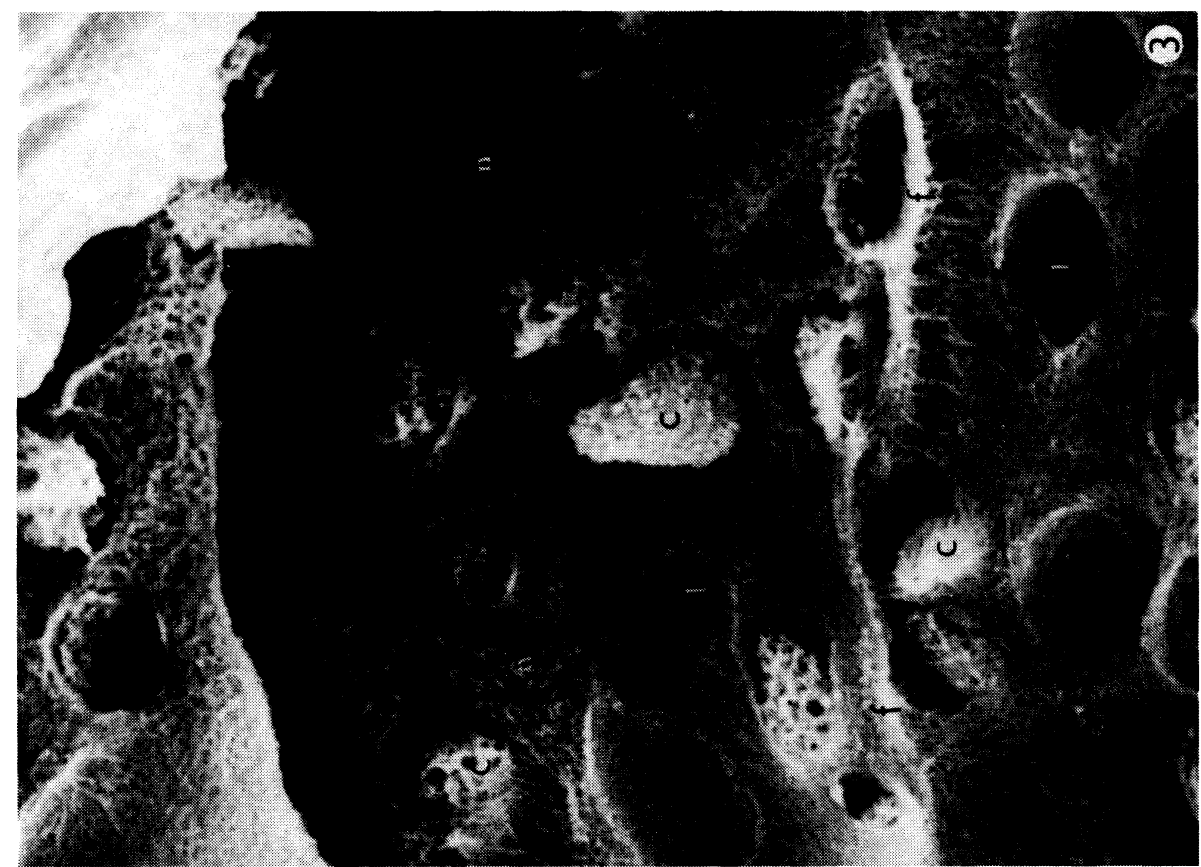

Fig. 3: Detail of Fig. 2. Empty lacunae of chondrocytes (1). Chondrocytes still present in lacunae (c), bundles of collagen fibrils surrounding lacunae in the intercellular matrix (f); their network (n) in the pericellular matrix. $\times 3000$.

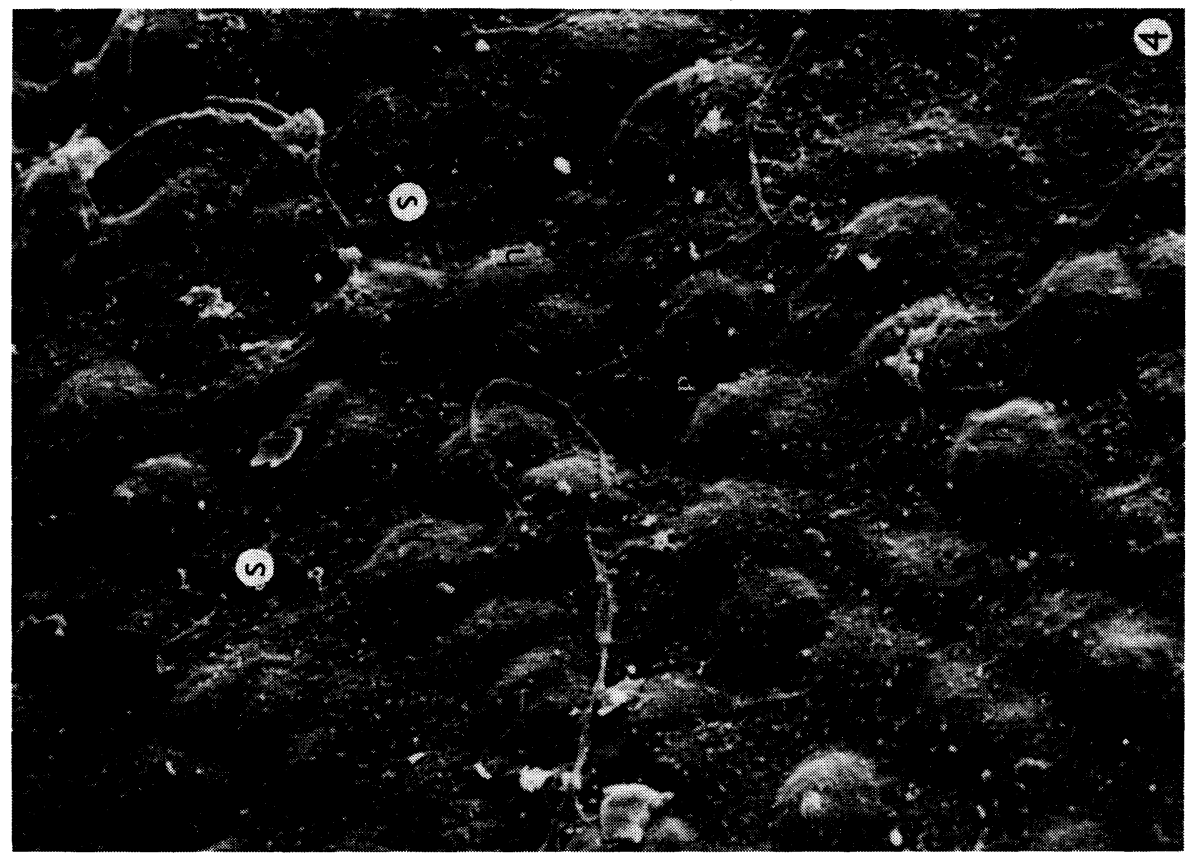

Fig. 4: Surface of articular cartilage in a feline foetus at 48 days. Rounded and elliptical elevations (h) and small depressions (p). Smooth surface areas (s) amongst groups of chondrocytes. $\times 1500$. 
Plate III.

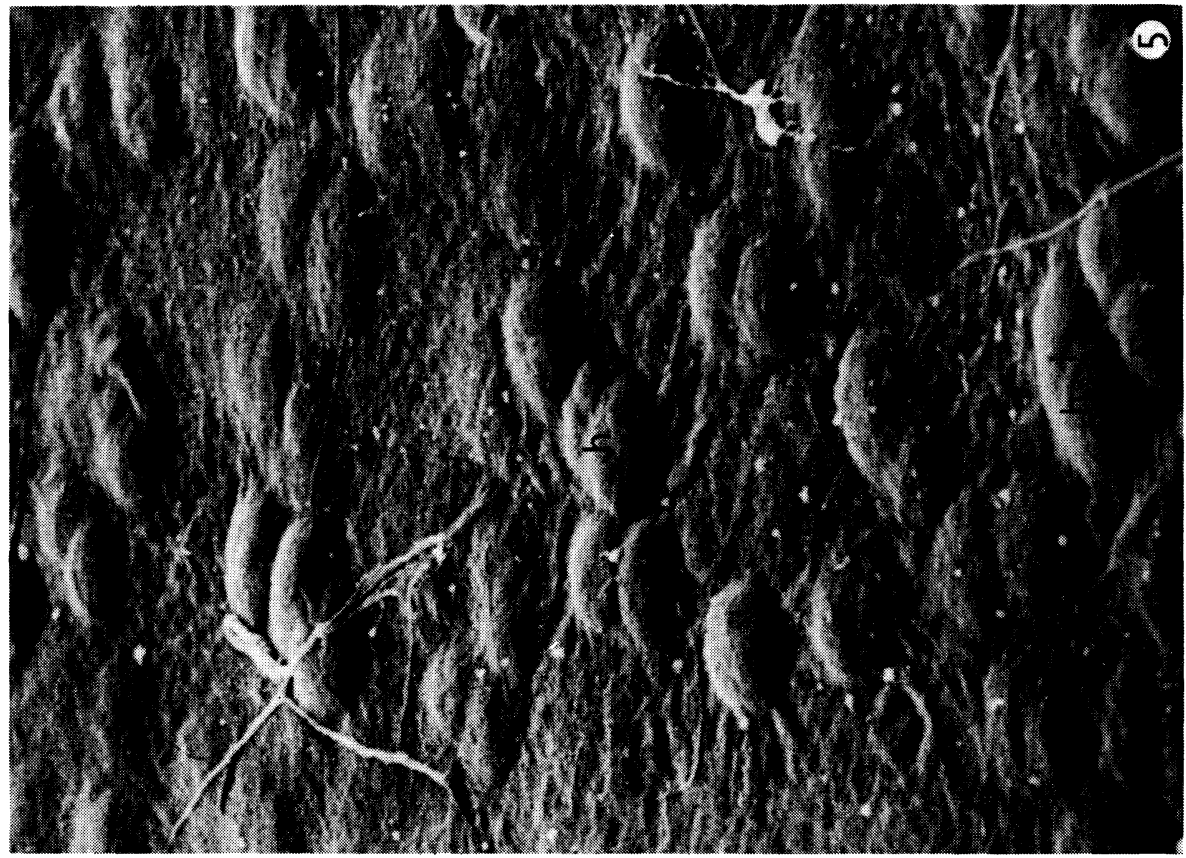

Fig. 5: Part of the surface of feline articular cartilage at 4 days after birth. Groups of ovoid elevations consisting of 2 or 4 cells $(\mathrm{h})$, grooves on their surfaces (i). Wrinkled regions $(\mathrm{m}) . \times 150$.

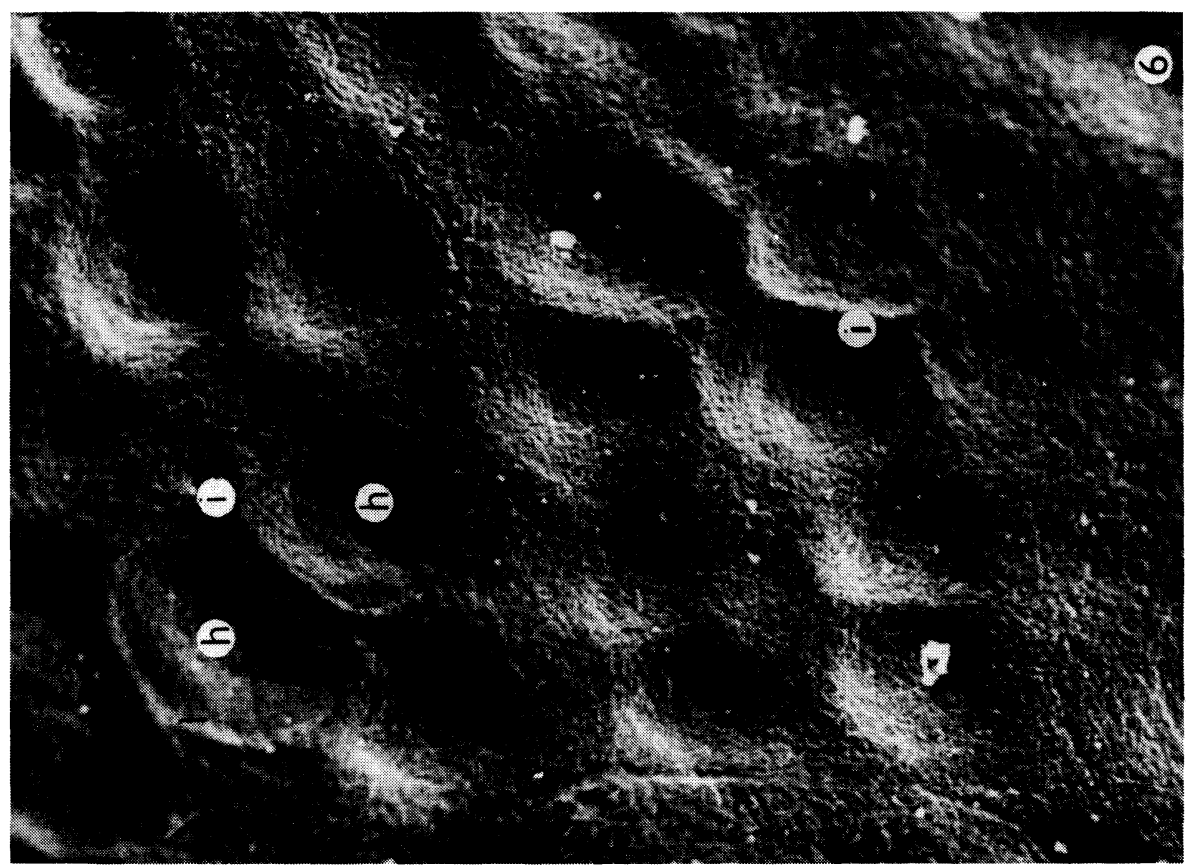

Fig. 6: Group of elevations on the surface of feline articular cartilage at 8 days after birth. Rounded elevations (h), with grooves (i), surrounded by valla (I) $\times 3000$. 


\section{Plate IV.}

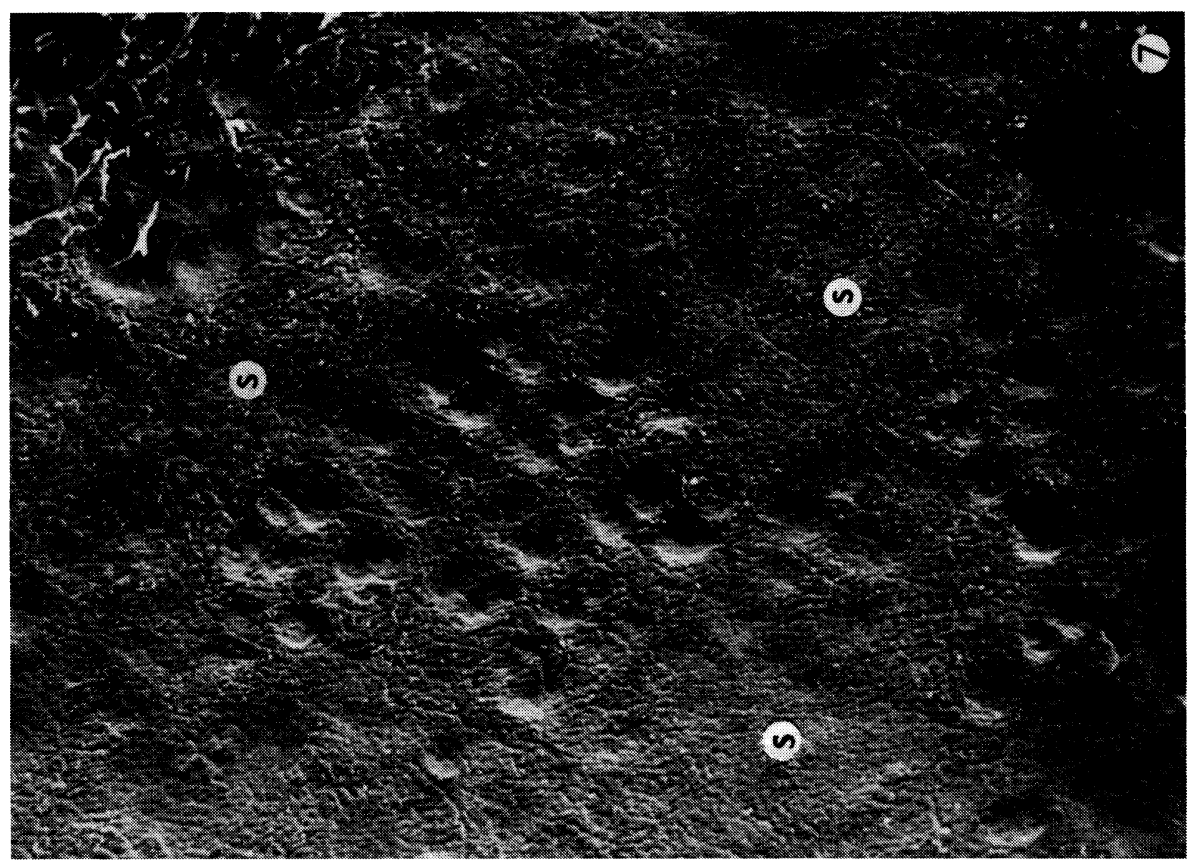

Fig. 7: Part of the cartilage surface not subjected to pressure forces in the cat at 43 days after birth. Groups of 3 to 4 elevations (h), extensive flat regions (s) with a finely wrinkled chondrosynovial membrane. $\times 450$.

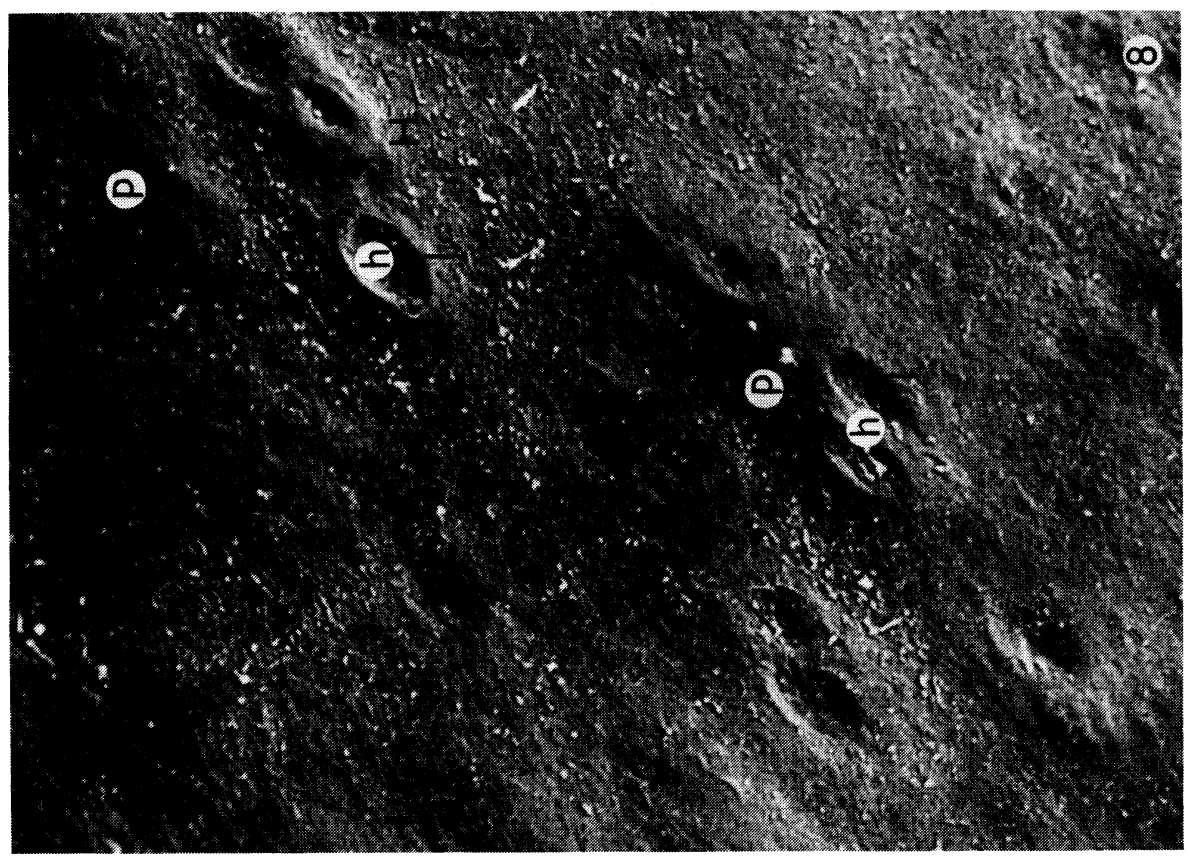

Fig. 8: Part of the cartilage surface subjected to pressure forces in the cat at 43 days after birth. Single chondrocytes or their pairs (h) are bordered by furrows (I) and are sunken in the intercellular matrix. Broad, shallow depressions (p) are separated by ridges $(\mathrm{H}) . \times 1500$. 